\title{
Sustainable Complex Triangular Cells: Case Study - Envira River Isolated Indians in Western Amazon
}

\author{
Marcelo S. Sthel ${ }^{1} \&$ José G. R. Tostes ${ }^{1}$ \\ ${ }^{1}$ Centro de Ciência e Tecnologia, Lcfis and Lcqui, Universidade Estadual do Norte Fluminense-UENF, Rio de \\ Janeiro, Brazil \\ Correspondence: Marcelo Silva Sthel, Centro de Ciência e Tecnologia, Universidade Estadual do Norte \\ Fluminense (UENF), Av. Alberto Lamego, 2000, Campos dos Goytacazes Rio de Janeiro, Brazil. Tel: \\ 55-22-2739-7229. E-mail: sthel@uenf.br
}

Received: June 11, 2012 Accepted: July 23, 2012 Online Published: July 26, 2012

doi:10.5539/jsd.v5n8p92 URL: http://dx.doi.org/10.5539/jsd.v5n8p92

\begin{abstract}
We display a simplified geometrical model which aims to facilitate the understanding of current environmental problems: the sustainable complex triangular cell model. At the present stage of the human society, the cell will be represented as a scalene triangle, symbolizing distorted relationships among Energy, Economy and Ecology. By applying the concept of sustainability, it becomes possible to propose a transformation of the irregular triangle into an equilateral one, indicating a more symmetrical relationship among the $3 \mathrm{E}$ and, finally, the building up of a hexagonal regular community formed by these equilateral triangles. As a limiting case, one can admit a geometrical collapse of that hexagon in the case study here discussed: the recent discovering of an isolated Indian tribe at Amazon.
\end{abstract}

Keywords: model, triangular cells, complexity, sustainability

\section{Introduction}

The complexity of coupling between human and natural system - CHANS (Liu, 2007a; 2007b), has always been present since the dawn of human society. Therefore, from the first hominids to the appearance of the genus homo, a set of complex interactions with the biophysical environment of the planet has always existed. Particularly, the climate interferences have produced important alterations in the morphological evolution of the human kind (Susan, 2007) and in the behavior evolution of our primordial social brain (Dunbar \& Schltz, 2007). Since the beginning of human society history, the range and the intensity of those interactions have been enhanced in a growing way, exhibiting a great inflection since industrial revolution. Historically, the vast majority of those interactions were locally restricted; wars and migrations were exceptions. But presently, such interactions are being extended to regional, continental and even global level (Liu, 2007a).

Global environmental problems have reached worrying levels at the present; From the 70's, awareness to these events has started. The human society has been faced with a question: the environment! Could we continue to exploit natural resources indefinitely? How to face the hard environmental problems as regard the great expansion of economical area from the fifty decade, in which the consumption rates have grown up abruptly? Material progress that a portion of human population has reached in recent years has been achieved largely through the scientific and technological levels attained by man, combined with a predatory activity of the natural resources available on the planet. Nevertheless, the maintenance of life quality in its totality requires that some environmental parameters are kept within a tight control (i.e., within minor fluctuations). Changes in the environment, such as chemical pollution, ocean acidification, changes in the biogeochemical cycles, changes in the land using, depletion of stratospheric ozone, climate changes, biodiversity shrinking and the scarcity of natural resources affect the human society in a global fashion (Rockstrom, 2009; Crutzen, 2002; Steffen, 2007; Schmidt, 2010; Kevin, 2012). Natural resources are widely employed and incorporated in complex social-ecological systems (SESs) (Ostrom, 2009). So, these SESs contain several subsystems and internal variables, analogous to the organisms composed by organs; the organs composed by organ tissues; organ tissues weaved by cells and cells, in turn, by proteins (Pennisi, 2003).

Among several global environmental changes, climate changes have touched the world public opinion more effectively. The global warming (Hansen, 2008; Rosenzweig, 2008; Solomon, 2009; Nathan, 2008; Yarrow, 2009; 
Lacis, 2010; 2012) is pointed as the driving force of these climate changes, which has produced great alterations, such as: defrosting in mountains, lakes and seas, increase in the ocean levels and acidity, increase in the hurricanes intensities and fluctuations in the rain patterns (aridity, inundation). Thus, global warming has caused great damages to economy (Stern, 2006). The worldwide concern with the reduction of greenhouse gases is a reality discussed in major world economic forums and international environmental agreements to reduce greenhouse gases, e.g. Kyoto. The mere advertisement of a geopolitical amplification of the mentioned reduction for a pos-Kyoto accord provokes intensive and polemic debates. It is necessary to modify the current energetic matrix, based on fossil fuels since industrial revolution.

The challenges of actual society for the XXI century are enormous; we do not want to loose the material progress achieved by human knowledge via technology. Then, to sustain the already conquered economical progress, we necessarily have to alter the planetary energetic matrix, in order to reduce greenhouse gas emission (Meinshausen, 2009; Myles, 2009), to prevent more complex scenarios for climate changes. Therefore, we should find an equilibrium among non separable and complex relationships which permeates the three agents involved in these questions: Economy, Energy and Ecology (Environment) (Rifkin, 2009). In the present work we introduce a geometrical model to simplify the understanding of the linkages between the $3 \mathrm{E}$ applied to an individual (man) of any culture of the present human society. Concepts like eco-efficiency (ICC, 1991; UNEP, 1998) has been proposed since the eighties, just when more harmonious and symmetrical connections between Economy and Ecology, characterizing an edge $2 \mathrm{E}$ or, in other words, a one-dimensional model, has been searched. Since then, articulated ecological and economical themes has been extensively debated (Hornborg, 1998; 2001; Costanza, 1991; Odun, 1989; Boulding, 1966). We present here a new proposal, in which it will be explored the present relationships among the $3 \mathrm{E}$, suggesting a bi-dimensional model that takes into account the Energy concept - going beyond one-dimensional ones - due to the importance that such a concept has acquired in the present discussions about climate changes via the IPCC, 2007, report (IPCC, 2007a; 2007b). The three E concepts occupy, each one, a vertex of a bi-dimensional triangle, whose area may be considered as representing an ecological footprint of each individual (WWF, 2006; Dias, 2006; Sthel, 2007; 2008; Cesar, 2011). This model will be applied to a case study of an Indian group recently discovered at the edges of the Envira River in the Acre State at Western Amazon in Brazil.

\section{Methods}

\subsection{Sustainable Triangular Cells}

We propose, in a preliminary way, a qualitative and synthetic geometrical model that can describe the present status of man-nature conflict. Then, we introduce the model of sustainable triangular cells, in which, a triangle ("cell") is employed as a geometrical representation to sign inseparability of the relationship between the three vertexes (3E), Figure 1. A point in the geometrical center of this triangle represents any individual of the present society, since this individual - in spite of being extremely differentiated by social conditions - is the main originator of ecological and economical problems, once he (she) is a great consumer of natural resources, particularly energy, besides commanding the productive systems, i.e., the economy. Then, man appears as the central personage in our representation of the patterns of $3 \mathrm{E}$ complex sustainable triangular cells; each $3 \mathrm{E}$ triangle is an open system, i.e., it can exchange matter and energy with the environment, representing a complex coupling between man and natural systems (CHANS). We define the triangle area as the survival needs of each individual, i.e., his ecological footprint. There also exist three arrows which traverse, each one, the middle point of each edge of the triangle, pointing to the center of the triangle: man. These arrows represent a prior tendency characterized by individual consumption and intensive utilization of energy and material goods (exchanged with environment), whose disordered environmental configuration suggests the formation of a scalene triangle, i.e., with asymmetrical relationships between the 3Es. As a consequence, in present society, there is a growing trend in the area of this triangle, as a result of the increased individual and global ecological footprint. The result is thus a departure from the vertices of the triangle (3E) and, consequently, an increase in the asymmetry of these concepts, generating an increasing environmental unsustainable process. 


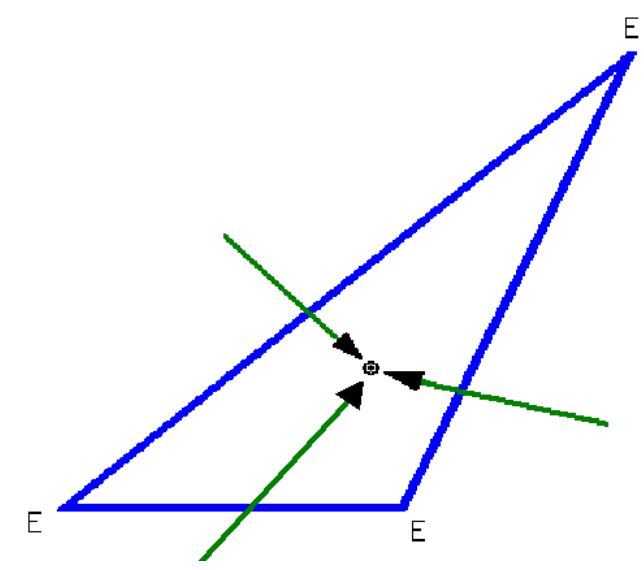

Figure 1. Representation of an individual in the present-day (scalene triangle) society $3 \mathrm{E}$

The actual society is multilayered, with enormous economical inequality that tends to be strongly articulated with the planetary capitalist matrix, generating a great disorder from the socio-environmental viewpoint. Among the individuals of this society, there exists a per capita consumption, which is extremely differentiated. This situation leads us to a context of extreme social complexity (Luhmann, 1995; Arthur, 1998). So, an irregular (scalene) triangular representation leads to the complex triangular cells model. The impossibility of separation of the three main concepts (Energy, Economy, and Ecology) drives them to a feedback among themselves, forming cyclical loops that exchange matter and energy (Harold \& Eric, 2007) with the environment. This is a characteristic of open systems, which leads to complex dynamical and self-regulating systems ${ }^{1}$, alike to living systems. For representing all individuals, we have a multitude of scalene triangles with their varied areas that together may represent the footprint of the entire society. So, these triangles are able -preliminarily - to picture and describe the social, economical and cultural differences among any individuals of that society. Therefore, the scalene triangular patterns (the complex cell) represent a description of the chaotic recovery of the individual in the modern society.

In order to make the society-environment relationships more harmonious and sustainable (Shaharir, 2012), we propose a new triangle, the equilateral triangle (Figure $2 \mathrm{~b}$ ), where the $3 \mathrm{E}$ relationship is symmetric. This real accomplishment depends on a great individual advance of individual conscientiousness in preserving natural resources (sustainability), which, in turn, implies in a possible reduction of the triangle area (individual footprint), as regard the original scalene triangle (Figures $2 \mathrm{a}, 2 \mathrm{~b}$ ). But even with the reconstruction of the individual through the application of the "sustainable" concepts, the direction of these arrows is still toward to the individual himself, indicating an appreciation of individual consumption of natural resources (Figure 3a). Thus, this situation could lead to a further increase in the triangle area, even in the equilateral triangle and we could still have high environmental costs. So, the greatest humanity challenge would be inverting such arrows, in the reverse outward direction (Figure 3b), creating new cultural paradigms. In this new representation, the individual would accept collective solutions (sharing natural resources), no longer being the isolated individual of the previous representation (arrows inward). Thus, the individuals would accept to reduce the use of natural resources through sharing them. For example, there could be a reduction in the community energy consumption where they live through the collective transport implementation. Therefore, the area of the equilateral triangle (Figure $3 \mathrm{~b}$ ) and, consequently, the ecological footprint of the individual and the whole community could be reduced. 


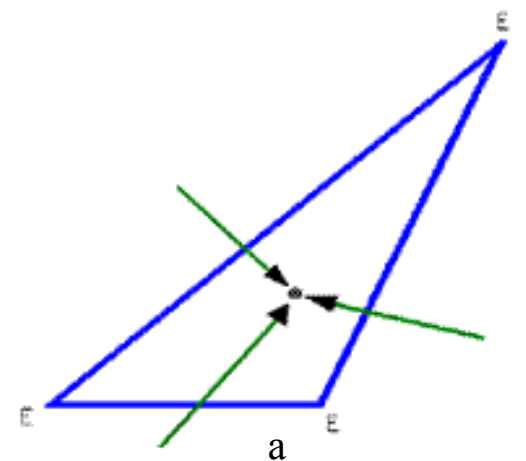

a

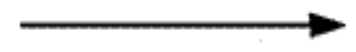

Figure 2. Transformation, via sustainability and within the same economical matrix, from a scalene to an equilateral triangle (society) $3 \mathrm{E}$
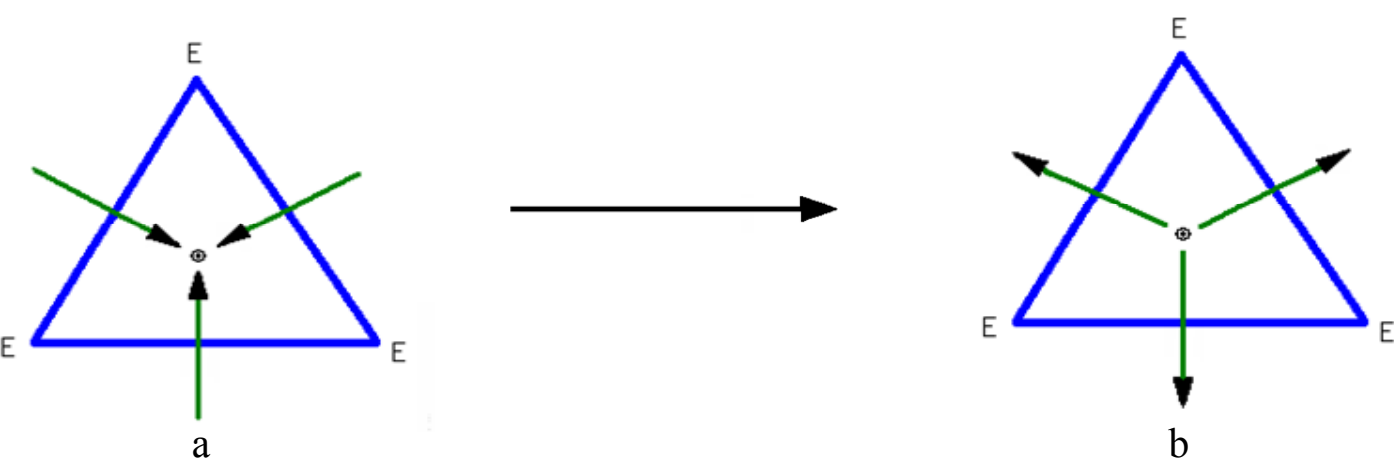

b

Figure 3. Arrows inversion in equilateral triangle: towards a new pattern (or cultural paradigm) of sustainability

When the arrows are inverted "outward" we can couple a collection of equilateral triangles in a geometrical fashion in order to represent a community, where each individual, in turn, is represented by a triangle and, for each group of six individuals, a pattern of a regular hexagon is formed. In these hexagons, the relationships among the members of this ecological community are not linear, involving multiple feedback loops, i.e., a sustainable human community sharing natural resources (Crutzen, 2002). Thus, the several relationships among its members must be interdependent, a reciprocal dependency of all individuals of this community. To strength the community means to strength the relations among individuals (cooperation). The concept of arrows reversal premised the construction of a regular hexagonal structure (Figure 4), which allows other geometrically similar structures to engage with each other. So, it is generated a model of a sustainable social system that: i) follow exchanging energy and matter with its environment, i.e. a structurally open system and ii) possesses a closed web pattern of growing, i.e. it is a self-organized system (Kaufmann, 1993; Holland, 1996; Levin, 1999; Bak, 1996) (Note 1). From the present/hegemonic chaotic model of asymmetrical scalene triangle for each individual, one can generate order through a non deterministic change in the cultural paradigm that leads to an emergency of a new self-organized system. Then, we obtain an order through the regular hexagonal relationships that allows indefinitely couplings up to the formation of self-organized representations of great number of individuals. In fact, the representation of the outward arrows indicates the capacity to maintain interdependence among individuals belonging to the set of regular hexagons, thus forming a network structure, which share resources and environmental services sustainably. As an example of pre-human life, we may quote the complexity (Watkins, 2008; Wards et al., 2008) of a great fish's shoal that self organize them to be protected from predators. We are also utilizing in this model the concept of collective intelligence (Patten, 1991; Parrish \& Edelstein-Keshet, 1999). 


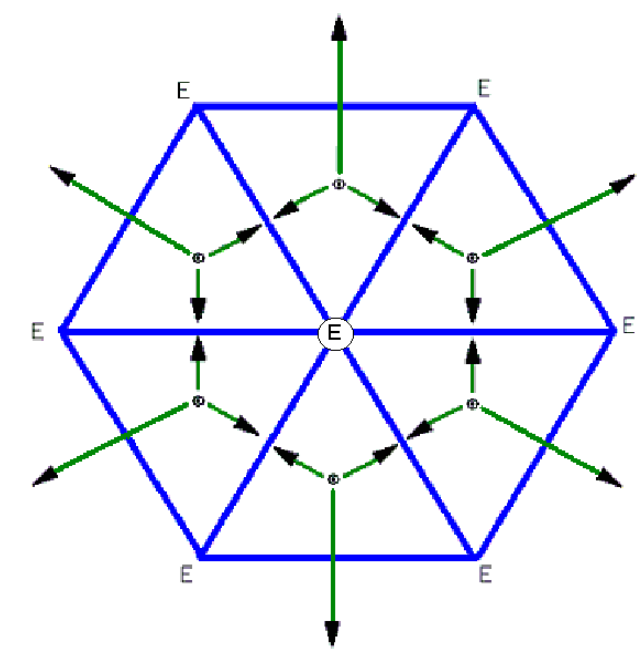

Figure 4. Regular hexagonal structure: sharing natural resources (cooperation)

We consider in the present model that the sharing of natural resources, will lead to a reduction in the ecological footprint of that regular hexagonal community. Consequently, it leads to a reduction in the total area of hexagon; such an area is less than the sum of the areas of the respective individual equilateral triangles that have generated it. Such a reduction has occurred because the new hexagon formation is a collective phenomenon (National Geographic, 2007; News, 2007; Brown \& Lauder, 2000; Sunstein, 2006), in fact, by changing the cultural paradigm, the individual would be able to re-pact the employment of natural resources in a rational fashion (to be decided by each community) (Crutzen, 2002), For example: employment of renewable energies or collective transport, energetic efficiency programs, large recycling program, efficiency in the employment of water resources, sustainable use of land and a rigid pollution control.

The triangular model of the 3E could be equally fitted if, instead of the vertex "Energy", we have used "Entropy". In fact, we remember that the Second Law of Thermodynamics deals with the state function entropy (at equilibrium), which in turn may be envisaged as describing a certain quality of energy (Georgescu-Roegen, 1995; 1971), i.e. the dissipated energy in physical-biological processes and no more re-available (recycling) in new physical-biological processes. So we can freely exchange "Energy" per "Entropy" in the triangular model.

\subsection{A Case Study: Envira River Isolated Indians in Western Amazon}

An Indian tribe at Amazon was recently discovered (May, 2008) by a team of the "Frente de Proteção Etnoambiental da FUNAI (Fundação de Proteção ao Índio)", Brazil, coordinated by João Meirelles (Meirelles, 2009) and documented by the photographer Gleison Miranda, at the shores of Envira River in the Acre State, Western Amazon (Terra Magazine, 2008). After a flight of almost twenty hours in a mono-motor plane, it was obtained a set of photographs of the Indians (Terra Magazine, 2008) of one of the four ethnical isolated groups which live in the Acre State (Brazil), frontier with Peru. The women and children have run away to the forest searching for protection, while the tribe warriors have reacted and fired arrows toward the plane (Figure 5). They are called "invisible Indians" due to the difficulties in their localization. Such a tribe was chosen as a first case study for applying our model of sustainable complex triangular cells. One is dealing here with a tribe of few individuals, remaining from Indians that live in the Brazil-Peru frontier (survival international, 2008; BBC news, 2008). Intensive lumber dealer activities and the arrival of prospectors in Peru have placed those ethnical groups in flight towards Brazil territory. 


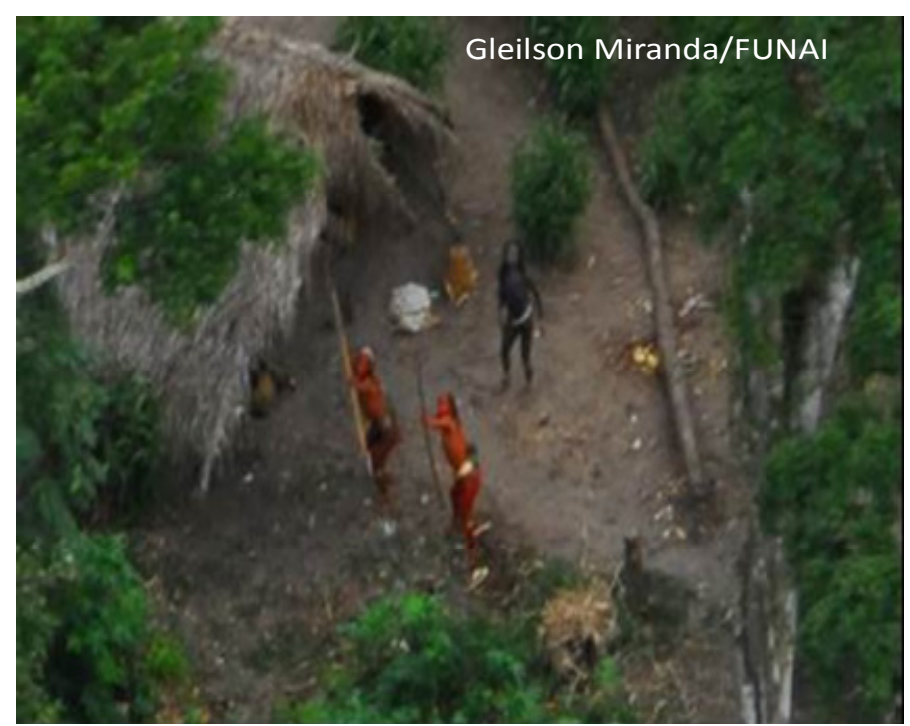

Figure 5. Photographed by the first time, the "invisible Indians" react firing arrows on the airplane, in the hinterland of the Acre State, Brazil (http://www.terramagazine.terra.com.br)

These few Indians have not yet contacted our civilization, living in a hunting/collecting economy and using a rudimentary agriculture for subsistence. As a consequence, they do not consume any product generated by civilized human hands, as clothes, domestic utensils, raw materials for house building up, fertilizers, etc. They also do not consume energy generated by any device that exhibits civilized human intervention, and there is no definition for "ecology" in this kind of community due to its highly sustainable relationship with environment. The market economy defined by "civilized" man is practically inexistent. They inhabit in collective longhouses (Figures 6 and 7), constituting a community that shares natural resources in a efficient way (Crutzen, 2002), in a highly sustainable relationship with environment, practicing a kind of group intelligence, that helps the community surviving.

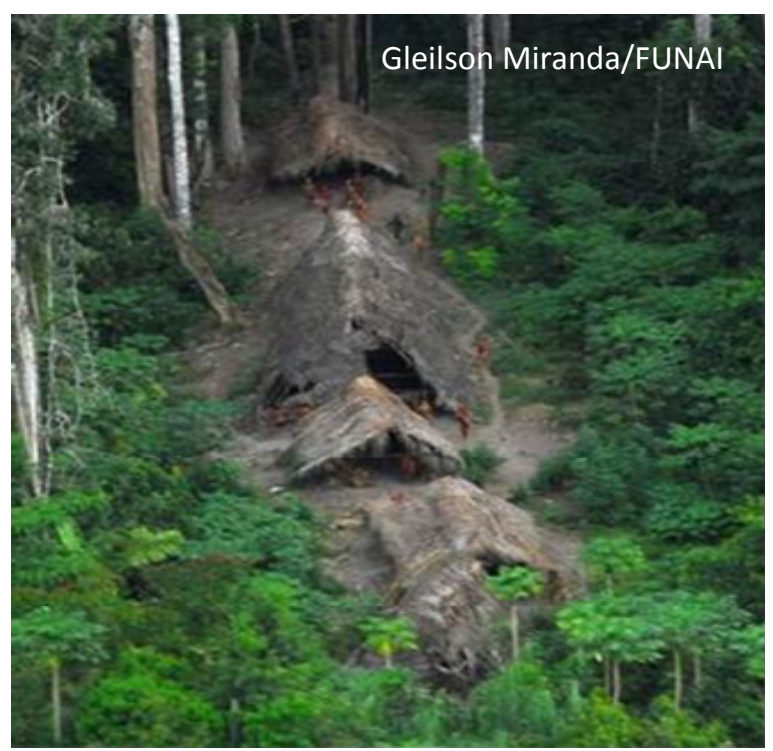

Figure 6. Aerial photograph of cabins of invisible Indians (http://www.terramagazine.terra.com.br) 


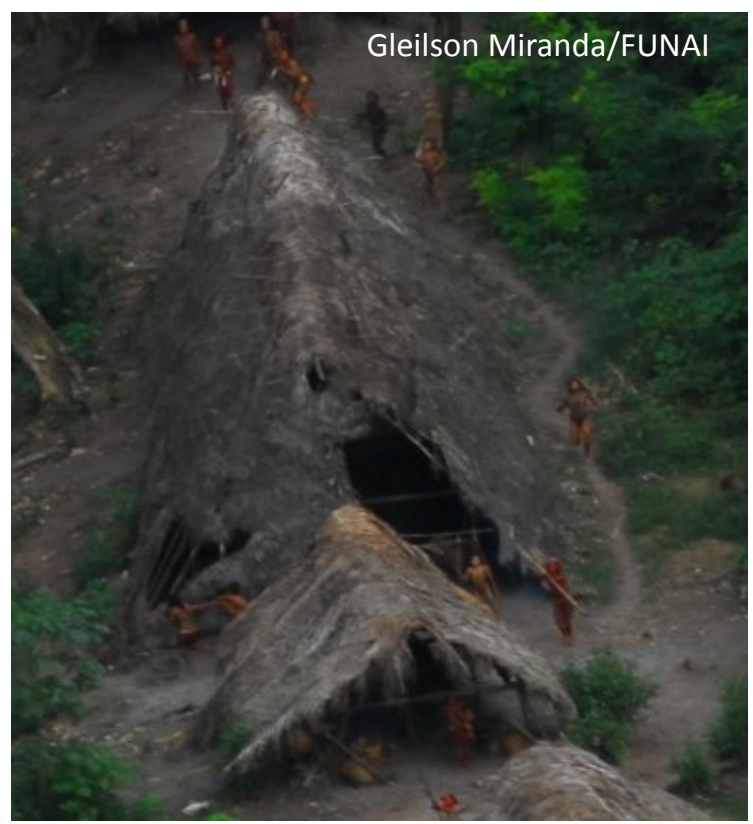

Figure 7. Amplified photograph of a cabin of invisible Indians (http://www.terramagazine.terra.com.br)

As a consequence, we could no longer separate the concepts (Economy, Ecology, and Energy) as we separate them in our present consume society, due to the perfect harmony between man-nature in the Envira River's case. Then, to represent an individual of this community, we should utilize, right from the start, the equilateral triangle (Figure $3 \mathrm{~b}$ ) and a case of perfect equilibrium among the three E vertexes. So, the equilateral triangle that should represent this individual (Indian) would tend to be linked to a phenomenon that could be labeled as "equilateral collapse" (Figure 8), in which its vertexes converge towards the triangle center, due to the inexistence of the concepts of economy, energy and ecology in this primitive community. This collapse leads to a sudden reduction of the triangle area, indicating a practically null ecological footprint for each individual. These invisible Indians are a well suited example of an application of the regular hexagonal model, Figure 4, where cooperation (News Focus, 2009) is a central characteristic of this community. By applying this collapse concept to this regular hexagon of Indians, a little circle is obtained. The area of the circle tends to be null, what amounts to a minimum ecological footprint for this community. We label this circular figure as "Necklace Society", in behalf of the invisible Indians of the Envira River (Figure 9). We have initially taken a single hexagon (six Indians) as an example, but we could include a greater number for the whole tribe. In fact, Figure 9, which exhibits the circle that represents the necklace society, indicates arrows outward and, as a consequence, indicates the possibility of interaction (cooperation) among individuals, i.e. new circular cells (necklaces) can be articulated leading to a web structure, contemplating other Indians. It is interesting to emphasize that the Indian society represents the limit of the environmental cost in the framework of the regular hexagon model, which is formed by sustainable equilateral triangular cells. These cells, in this present case study, become circles with a practically null ecological footprint. So, this is a case of an ideal sustainability. Nevertheless, the present civilization model cannot return to this lower limit, but this limit has existed in the dawn of human civilization and still amazingly endures today, as in the case of invisible Indians of the Envira River. The Figures 6 and 7 represents a look at the far past of human civilization. 


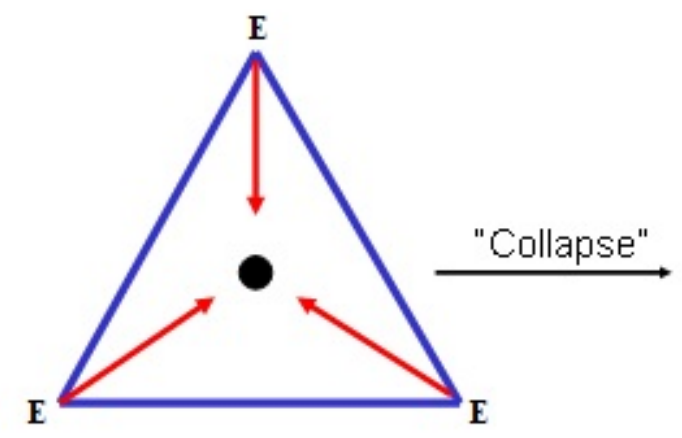

Figure 8. Collapse of an equilateral triangular cell for an individual (Indian)
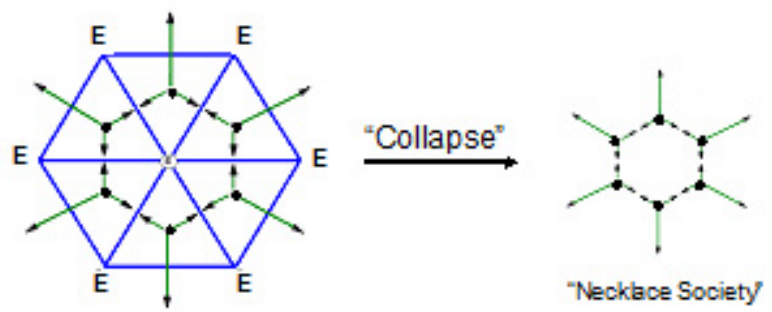

Figure 9. Collapse of regular hexagonal structure for the Indians society

Then, we have shown an example in which the man-nature relationships are in perfect harmony and, even if it sounds incredible, communities with few individuals living that model still exist; societies like these ones tend to be quickly extinguished due to the expansion of civilized men. The present civilization, in its very early stages, has lived such a situation, i.e. in the very beginning we were few individuals that have formed little groups sharing food and house and protecting each other from predatory menaces: a necklace society. We have since them evolved to greater communities in the form of hexagonal societies, in which we have begin a still elementary agricultural practice utilizing fire, plows and irrigation; we no longer were a necklace society; we already had, however small, our ecological footprint. We have then arrived at industrial revolutions and certainly from this point, we have dealt with massive using of fossil matter and energy, we have built up the present-day civilization. In this same industrial phase it has begun the effective "scalenization" of the equilateral triangles formed at the anterior regular hexagonal civilizations (agriculture era). In other words, there have been a growing deformation process of the hexagonal geometry to a point of total implosion of the hexagonal social structure. In this way, we have begun to transform ourselves in the individualized scalene triangles, complex cells with growing areas which leads to an enhancement of our ecological footprint due to the intensive use of natural resources. We have created a highly complex system from the socio-environmental viewpoint and we face the challenge of finding a new systemic (dynamical) stability point, i.e. we need to harmonize the three mentioned vital points: Economy, Energy, and Ecology. And we have to be conscious that this is one of the great - if not the greatest one - challenges of this century, which in turn is profoundly tied to the (western) search of a (re)articulation between society and nature.

\section{Results and Discussion}

We present in this work a simplified geometrical representation of three important concepts that are linked in real life (Economy, Energy, and Ecology). However, due to the present civilization model, these concepts seem to 
feed "insoluble" conflicts between society and environment. So, economy ("only" society) and ecology ("only" environment) seem two to be separable spheres of reality. In its turn, the use of energy seems to be decided only in the economical sphere, no matter its consequences for the ecological sphere (costs externalization of the use "exclusively" social of energy). When we have introduced the concept of "hexagonalization" of equilateral triangles, we have admitted a reduction in the hexagon area, as compared to the sum of areas of individual equilateral triangles which formed that hexagon. We are reducing the ecological footprint of the hexagon-community. Therefore, we are looking for the sharing of natural resources in order to reduce environmental impacts. This is not new in the mankind history and it is already being considered in the environmental anthropology. The very ancient change of cultural paradigm that amounts to the construction of the hexagonal model lead us to a central point about collective consciousness, that has already been experimented by our ancestors and that anthropologists have labeled as "devices of cultural buffering" (Hall, 2008; Kuhn \& Stiner, 2006). It is a factor in the behavior of a group - a technology inserted in a social organization, in a cultural tradition - which works as a guarantee of its bets on the risky game of natural selection. Mary Stiner and Steven Kuhn claim (Kuhn \& Stiner, 2006) that the first modern human appeared in Africa with one of those "buffer devices": an approaching to hunting/collecting activities that was efficient and resulted in a more diversified diet, increasing the chances of survival of the species. Eris Trinkhaus (Hall, 2008) goes farther and suggests that "among all devices of cultural buffer, maybe the most important one is the existence of the own society". He explains this affirmation conceptualizing the "buffering" function in terms of systemic feedback: big groups require more social interactions (Dunbar \& Schltz, 2007; Silk, 2007; Jolly, 2007; Gilbert \& Wilson, 2007) among their members, which, in turn, leads to a greater brain activity during childhood and adolescence, fostering greater complexity of language and, indirectly, increasing the average life expectancy. This longevity foments knowledge transmission from one generation to the other and creates, according to Chris Stringer (Hall, 2008), an "innovation culture" - the passage of practical abilities of surviving and techniques of devices production from the older to the younger members. We then conclude that this circle is closed and restarted by stimulating the own original "big group" to enhance itself (Note 2).

"The Homo erectus [by the sharing of natural resources] developed the first economy of hungering-collecting in which hunting animals were a significant part of the diet and resources were shared among the members of the group" (Leonard, 2002).

To understand the role of feeding in the human evolution, we must remember that the search for food, its consumption and, finally, its use in biological processes, are - all of them - critical aspects of the ecology of an organism. Another important concept is the "dynamical energy" (Leonard, 2002; 1997) among organisms and their environments, i.e. the expended energy in hunting compared to the energy acquired with the hunted product, which had important adaptation consequences for surviving and reproduction (Note 3). These two last components of the Darwinian aptitude are reflected in the way we estimate the energy stock of an animal. The maintenance energy is the energy necessary to sustain an animal alive. As the animal here considered is the man, we can propose that, in the Homo erectus society, energy, economy, ecology - obviously in a simplified way had a more harmonious relationship, approximating them to a hexagonal society (Figure 4). If we look behind, we can see that we have achieved success because we shared natural resources even to originally protect us from our natural enemies and from the climatic changes (Silk, 2007). It is amazing that, even today, these "invisible Indians" still exist, like the ones of the Envira River, which practice hunting and fishing just like in the ancient collector societies. Although they know a rough form of agriculture, which practically does not impact the environment in which they live, they keep on a harmonious relationship with this same environment, much alike our ancestors have done.

We have presented in this work a tentative of synthesis among complex relationships society-nature, through a very simple geometrical language, aiming at facilitating the understanding of global environmental questions. We have utilized a real example: the invisible Indians of the Envira River, to show the application of the model of sustainable triangular cells, via regular hexagonal geometrical construction and the collapse concept, emerging from that model, to the present case study.

We have also seen, observing Figures 2 and 3, that it was possible to describe a trajectory towards a sustainable society, via two consecutive stages of "geometrical" transformations of a socio-environmental process. Particularly, our equilateral triangular geometry (Figure 3a) of transition (arrows inward) represents an economic model that we are trying to build up for a supposed optimal (capitalist) economy that is seemingly "equilibrated", but rigorously speaking, is still untenable. In addition, the process delineated from a present state of art (see Figure 1) is not determinist, but a possible path to be created. Can we succeed in adopting a device of cultural buffering, which was already utilized in other periods of our history, in the complex conjuncture of the current 
society? Can we thus attenuate the environmental global menaces and follow the risky game of natural selection? The device of cultural buffering is possibly our alternative to amplify our adaptation ability in a planet whose biosphere exhibits growing entropy, with rupture of important natural cycles (Rockstrom, 2009; Folke, 2002), as carbon cycle, and a central environmental issue: the "climate changes" (Trenberth et al., 2006; Cziczo, 2009; Dim, 2012; Jarvis, 2012).

\section{Acknowledgements}

The authors would like to thank the Brazilian agencies CNPq, FAPERJ and CAPES for the financial support.

\section{References}

Arthur, W. B. (1999). Complexity and the economy. Science, 284, 107-109. http://dx.doi.org/10.1126/science.284.5411.107

Bak, P. (1996). How Nature works: the science of self-organized criticality. Copernicus Books. ISBN 0-387-94791-4

BBC news. (2008, May 30). Indian tribe found in Brazil. Retrieved from http://news.bbc.co.uk

Boulding, K. E. (1966). The economics of the comings spaceship earth in environmental quality issues in a growing economy. Johns Hopkins University Press, Daly, H. E.

Brown, P., \& Lauder, H. (2000). Collective Intelligence. In S. Baron, J. Field, \& T. Schuller, Social Capital: Critical Perspectives. New York: Oxford University Press.

Cesar, A. Poveda. (2011). A review of sustainability assessment and sustainability/ environmental rating systems and credit weighting tools. Journal of Sustainable Development, 4(6), 36-45. http://dx.doi.org/10.5539/jsd.v4n6p36

Costanza, R. (1991). Ecological economics: A research agenda. Structural Change and Economic Dynamics, 2(2), 335-357. http://dx.doi.org/10.1016/S0954-349X(05)80007-4

Crutzen, P. J. (2002). Geological of mankind. Nature, 415, 23. http://dx.doi.org/10.1038/415023a

Cziczo, D. J. ( 2009). Inadvertent climate modification due to anthropogenic Lead, Nat. Geosci. 499, 1- 4.

Dias, G. F. (2006). Human Ecological Footprint and Sustainability, S. Paulo, Gaia (2nd ed.).

Dim Coumou, Stefan Rahmstorf. (2012). A decade of weather extremes. Nature Climate Change, 2, 491-496. http://dx.doi.org/10.1038/nclimate1452

Dunbar, R. I., \& Schltz, S. (2007). Evolution in the social brain. Science, 317, 1344-1347. http://dx.doi.org/10.1126/science. 1145463

Folke, C. S., Carpenter, T., Elmqvist, L., Gunderson, C., Holling, S., \& Walker, B. (2002). Resilience and Sustainable Development: Building Adaptive Capacity in a World of transformations. Amb., 31, 437- 440.

Gavin, A. S., Reto, A. R., Ron, L. M., \& Andy, A. L. (2010). Attribution of the present-day total greenhouse effect. J. Geophys. Res., 115, D20106. http://dx.doi.org/10.1029/2010JD014287

Georgescu-Roegen, N. (1995). La décroissance: Entropie-Écologie-Économie. Éditions Sang de la terre, Paris.

Georgescu-Roegen, N. (1971). The entropy law and the economic process. Cambridge: Harvard UP.

Gilbert, D. T., \& Wilson, T. D. (2007). Prospection: Experiencing the Future. Science, 317, 1351-1354. http://dx.doi.org/10.1126/science.1144161

Hall, S. S. (2008, October). Neanderthals, National Geographic.

Hansen, J., Sato, M., Kharecha, P., Beerling, D., Berner, R., Masson-Delmotte, V., ... Zachos, J. C. (2008). Target atmosphere $\mathrm{CO}_{2}$ : Where Should Humanity Aim. Op. Atmos. Sci. J., 2, 217-231. http://dx.doi.org/10.2174/1874282300802010217

Harold, M., \& Eric, S. (2007). Energy flow and the organization of life. Complex., 13, 51-59. http://dx.doi.org/10.1002/cplx.20191

Holland, J. H. (1996). Order: how adaptation builds complexity. Basics Book.

Hornborg, A. (1998). Towards an ecological theory of unequal exchange: Articulating world system theory and ecological economics. Ecol. Econ., 25, 127- 36. http://dx.doi.org/10.1016/S0921-8009(97)00100-6

Hornborg, A. (2001). The Power of the Machine, Global Inequalities of economy. Technology and Environmental (Alta Mira Press, Oxford, UK). 
International Chamber of Commerce (ICC), the Business Charter for Sustainable Development, Paris. (1991).

IPCC. (2007a). Report of Working Group I, The Physical Science Basis. IPCC, Paris.

IPCC. (2007b). Report of Working Group II, Impacts; Adaptation and Vulnerability. IPCC, Bruxelas.

Jarvis, A. J., Leedal, D. T., \& Hewitt, C. N. (2012). Climate-society feedbacks and the avoidance of dangerous climate change. Nature Climate Change, 2. http://dx.doi.org/10.1038/nclimate1586

Johan, R., Will, S., Kevin, N., Åsa, P., F. Stuart, C. I., Eric, F. L., ... Jonathan, A. F.. (2009). A safe operating space for humanity. Nature, 461, 472-475. http://dx.doi.org/10.1038/461472a

Jolly, A. (2007). The Social Origin of Mind. Science, 317, 1326-1327. http://dx.doi.org/10.1126/science.1144284

Kauffmann, S. A. (1994). Origins of order. Oxford University Press. Journal of Evolutionary Biology, 7(4), 518-519. http://dx.doi.org/10.1046/j.1420-9101.1994.7040518.x

Kevin J. F., Jerry C. B., Mark E. B., John A. R., Darren R. C., John B., ... Glen L. W. (2012). Changes in pH at the exterior surface of plankton with ocean acidification. Nature Climate Change, 2, 510-513. http://dx.doi.org/10.1038/nclimate1489

Kuhn, S. L., \& Stiner, M. C. (2006). What's a mather to do! The Division of Labor among Neanderthals and Modern Humans in Eurasia. Curr. Antrop., 47, 953-981. http://dx.doi.org/10.1086/507197

Andrew, A. L., Gavin, A. S., David, R., \& Reto, A. R. (2010). Atmospheric $\mathrm{CO}_{2}$ : Principal control knob governing Earth's temperature. Science, 300, 356-359. http://dx.doi.org/10.1126/science.1190653

Lacis, A. A. (2012). Greenhouse effect. In Guoxiana Liu (ed.), Greenhouse gases-emissions, measurement and manager. Crocia, Intech.

Leonard, W. R., \& Robertson, M. L. (1997). Rethinking the energetics of bipedality. Curr. Anthropol., 38, 304-309. http://dx.doi.org/10.1086/204614

Leonard, W. R. (2002). For thought dietary change was a driving force in human evolution. Science. Amer., 74-83.

Levin, S. A. (1999). Fragile Dominion: Complexity and the commons. Perseus Books.

Liu, J. (2007a). Complexity of coupled human and natural systems. Sci., 317, 1513-1516. http://dx.doi.org/10.1126/science.1144004

Liu, J. (2007b). Coupled human and natural systems. Amb., 36, 639-649.

Luhmann, N. (1995). Social System. Stanford University Press.

Meinshausen, M., Meinshausen, N., Hare, W., Raper, S. C. B., Frieler, K., Knutti, R., ... Allen, M. R. (2009). Greenhouse gas emission targets for limiting global warming to $2^{\circ} \mathrm{C}$. Nat., $458,1158-1162$. http://dx.doi.org/10.1038/nature08017

Meirelles, J. C. (2009, April). Pela liberdade dos índios. National Geographic.

Miller, G. (2007). All Together Now-Pull. Science, 317, 1338-1340. http://dx.doi.org/10.1126/science.317.5843.1338

Myles R. A., David J. F., Chris H., Chris D. J., Jason A. L., Malte M. \& Nicolai M. (2009). Warming caused by cumulative Carbon emissions towards the trillionth tone. Nature, 458, 1163-1166. http://dx.doi.org/10.1038/nature08019

Nathan, P. G., Stone, D. A., Stott, P. A., Nozawa, T., Karpechko, A. Y., Hegerl, C. G., ... Jones, P. D. (2008). Attribution of polar warming to human influence. Nat. Geosci., 1, 750-754. http://dx.doi.org/10.1038/ngeo338

National Geographic. (2007). Collective intelligence, July.

Odun, E. P. (1989). Ecology and our endangered life-support Systems. Sinauer Associates.

Ostrom, E. (2009). A general framework for analyzing sustainability of social-ecological systems. Science, 325, 419-422. http://dx.doi.org/10.1126/science.1172133

Parrish, J. K., \& Edelstein-Keshet, L. (1999). Complexity, Pattern, and Evolutionary Trade-Offs in Animal aggregation. Science, 284, 99-101. http://dx.doi.org/10.1126/science.284.5411.99

Patten, B. C. (1991). Network Ecology. In Higashi, Me T. O. Burns (eds.), Theoretical Studies of Ecosystems: The Network Perspective. Cambridge University Press, New York. 
Pennisi, E. (2003). Tracing Life's Circuitry. Science, 302, 1646-1649. http://dx.doi.org/10.1126/science.302.5651.1646

Pennisi, E. (2009). On the Origins of Cooperation. Science, 325, 1196-1199. http://dx.doi.org/10.1126/science.325_1196

Prigogine, I., \& Stengers, E. (1984a). A nova aliança. Brasília: UNB.

Prigogine, I., \& Stengers, E. (1984b). Order out of chaos. New York: Bantam.

Rifkin, J. (2009). The empathic civilization: the race to global consciousness in a world in crisis. Penguin, New York.

Rosenzweig, C., Karoly, D., Vicarelli, M., Neofotis, P., Wu, Q., Casassa, G., ... Imeson, A. (2008). Attributing physical and biological impacts to anthropogenic climate change. Nature, 453, 353-357. http://dx.doi.org/10.1038/nature06937

Shaharir, M. Z. (2012). A new paradigm of sustainability. Journal of Sustainable Development, 5(1), 91-99. http://dx.doi.org/10.5539/jsd.v5n1p91

Silk, J. B. (2007). Social Components of fitness in primate groups. Science, 317, 1347-1351. http://dx.doi.org/10.1126/science.1140734

Site, T. M. (2008, May 23). Isolated indians was photographed for the first time at AC. Retrieved from http://www.terramagazine.terra.com.br

Solomon, S., Plattner, G., Knutti, R., \& Friedlingstein, P. (2009). Irreversible climate change due to carbon dioxide Emissions. PNAS, 106, 1704-1709. http://dx.doi.org/10.1073/pnas.0812721106

Steffen, W., Crutzen, P. J., \& McNeill, J. R. (2007). The anthropocene are humans now overwhelming the great

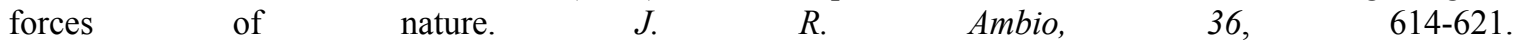
http://dx.doi.org/10.1579/0044-7447(2006)35[153:TAIAES]2.0.CO;2

Stern, N. (2006). Review: The Economics of Climate Change. UK. ISBN 0-521-70080-9.

Sthel, M. S., \& Tostes, J. G. R. (2008). Concept of Rationality in Applied Environmental Model for Sustainable Triangular Cells: Use Community Natural Resources. Paper presented at 4th Meeting of ANPAS Environmental Global Changes, Brasília.

Sthel, M. S., \& Tostes, J. G. R. (2007). Triangular cells and the sustainable IPCC: News paradigms. Paper presented at the 3th Regional Conference on Global Change: South America, USP, São Paulo.

Sunstein, C. R. (2006). Infotopia: How Many Minds Produce Knowledge. Oxford, United Kingdom: Oxford University Press.

Susan, A. C. (2007). Climatic Influences on the Evolution of early Homo Folia. Primat., 78, 365-388. http://dx.doi.org/10.1159/000105150

Terra magazine. Retrieved from www.terramagazine.terra.com.br/interna/O,OI2903379-EI6581,00.html

Trenberth, E. K., Moore, B., Karl, T. R., \& Nobre, C. (2006). Monitoring and Prediction of the Earth's Climate: A Future Perspective. J. of Clim. Spe. Sec, 19, 5001-5008.

Uncontacted tribe photographed near Brazil-Peru border. (2008). Retrieved May 29, 2008, from http://www. survivalinternational.org.br

UNEP and WBCSD. (1998). Cleaner Production and Eco - Effiency Complementary Approaches to Sustainable Development. ISBN 2-940240-02-7

Wards, A. J. W., Sumpter, D. J. T., Couzin, I. D., Hart, P. J. B., \& Kause, J. (2008). Quorum decision- making facilitates information transfers in fish shoals. PNAS, 105, 6948-6953. http://dx.doi.org/10.1073/pnas.0710344105

Watkins, N. W., \& Freeman, M. P. (2008). Natural Complexity. Science, 320, 323-324. http://dx.doi.org/10.1126/science.1151611

WWF-World Wild Life Foundation. (2006). Report for a living planet. Global Footprint Network, Switzerland.

Yarrow, A., Jason, P. B., Colin, A. C., Donna, R. F., Neal, M., Gifford, H. M., ... Alexander, P. W. (2009). Recent changes in a remote Artic lake are unique within the past 200,000 years. PNAS, 10, 1073. http://dx.doi.org/10.1073/pnas.0907094106 


\section{Notes}

Note 1. As we deal with open/self-organized systems it is possible to develop a modeling that uses theory of dynamical systems (Georgescu-Roegen, 1995) due to nonlinear characteristics which involve several feedback loops among individuals of such communities.

Note 2. The systemic concept of "cultural buffering" could be worked within the "complexity science" of Prigogine (Prigogine, 1984a; 1984b), once it was taken into account the rapidity with which such "buffering devices" would be transmitted or communicated through all the social system being analyzed. In the words of Prigogine, "the more complex is the system, the greater are the possibilities of, whichever is the case, certain fluctuations to become dangerous [...]. It is probable that in very complex systems, in which the species or individuals interact in a too much diversified fashion, the diffusion, the communications among all points in the systems are equally rapid $[\ldots]$ the rapidity of communication would determine the maximum complexity that the organization of a system could reach without becoming too much unstable".

Note 3. Just like in the concept of "cultural buffering", in Leonard (2002) it is displayed a systemic language of feedback, now articulating improved/shared diet, evolutional brain enhancement and a growing complex social behavior: after the initial spurt in brain growth, diet and brain expansion probably interacted synergistically: bigger brains produced more complex social behavior, which led to further shifts in foraging tactics and improved diet, which in turn fostered additional brain evolution. 